\title{
KULTUURI MÕJU EESTLASTE JA LEEDULASTE RUUMIKASUTUSELE
}

\author{
Rene Altrov
}

Ülevaade. Artikkel tugineb uurimusele, mis vaatleb kultuuri mõju ruumikasutusele erinevates suhtlusolukordades: kodus, töökeskkonnas ning väljaspool kodu ja tööd aega veetes. Uuringu eesmärk oli välja selgitada, millised on eestlaste ja leedulaste distantsikasutamise reeglid, kas need erinevad olenevalt suhtlussituatsioonist, kas eestlaste ruumikäitumine on ajas muutunud ning kas ilmneb erinevusi eestlaste ja leedulaste ruumikasutuses.

Andmeid koguti küsitluse teel, kus olid ette antud situatsioonikirjeldused nelja võimaliku käitumisvariandiga. Vastanute valikuid analüüsides tugineti G. Hofstede ja E. T. Halli kultuuriuuringutele. Uuritavad olid eesti ja leedu rahvusest kontoritöötajad. Eestlaste kohta koguti andmeid kahel korral - 1998. ja 2006. aastal. Leedulaste uurimus viidi läbi 2006. aastal.

Uurimus näitas, et väärtused ja eelistused võivad erineda sõltuvalt suhtlusolukorrast ja -keskkonnast - peresuhtes võivad esile tulla ühed kultuurinormid, töösuhetes ja vaba aega veetes teised. Võrreldes eestlaste 1998. ja 2006. aasta küsitluse andmeid, iseloomustavad eestlaste ruumikäitumist valdavalt individualistlikule ja maskuliinsele kultuurile omased väärtused, kuid võib näha nihet maskuliinsetelt väärtustelt feminiinsete suunas. Leedulaste puhul ilmnes, et nende ruumikäitumine on mitmekesisem kui eestlaste oma, olenevalt suhtlussituatsioonist tulid esile ka mitmed vastandlikud väärtused.

Võtmesõnad: prokseemika, ruumikäitumine, ruumikasutus, distants, eesti keel, leedu keel 


\section{Sissejuhatus}

Kommunikatsiooni hulka kuulub muuhulgas ka ruumikäitumine, ehk see, kuidas kasutame ruumi enda ümber ja missugust distantsi vestluspartneriga hoiame. Ruumisuhted ja territooriumi piirid mõjutavad otseselt meie igapäevaelu, kuigi teadvustame seda endale alles siis, kui meie territooriumi piire rikutakse. Kontroll oma territooriumi piiride üle on aga üks rahulolu tingimusi, mistõttu inimesed tahavad seda kaitsta ja ka käituvad vastavalt (Gifford 1997: 96, Preston 2005: 151). Ruum, mida inimene enda ümber vajab, on kindlate piiridega ja peegeldab tema identiteeti, vanust, sugu ja isikupära. Samuti kajastab distantsihoidmine suhtlejate sotsiaalseid ja personaalseid vahekordi, tundeid, omandit ning võimupositsiooni (Adler, Elmhorst 1992: 81-82, Gifford 1997: 101-105, Gudykunst, Ting-Toomey 1988: 124).

Eri kultuurides on omad ruumireeglid. Kultuuriti varieerub, kuidas tajutakse avarust, ülerahvastatust, distantsinormide rikkumist ja nendega arvestamist (Gudykunst, Ting-Toomey 1988: 124).

Paul Prestoni väitel on ruumikasutus inimestevahelises suhtluses üks vähem uuritud valdkondi (2005: 151). Seetõttu on antropoloog Edward T. Halli 1960. aastate distantsiuurimused (vt Hall 1990) tänapäevalgi aluseks ruumi ja ruumisuhteid uurivatele teadlastele. E. T. Hallilt pärineb ka termin prokseemika (Hall 1990: 1), mis tähendab ruumi kommunikatsiooniliste funktsioonide uurimist ehk seda, kuidas inimesed liigendavad ruumi suhtlusdistantsideks; kuidas korraldada ruumi kodus, töökohas jne; kuidas planeerida linnu ning nendevahelisi maa-alasid.

Inimestevahelises suhtluses on E. T. Hall eristanud nelja peamist distantsitüüpi: intiimne, isiklik, sotsiaalne ja avalik ruumivöönd (Hall 1990: 116-125). Neid distantse hoiab inimene sõltuvalt suhtlusolukorrast iseenda ja teiste vahel. See aga, millist distantsi mingis olukorras kasutatakse, sõltub suuresti kultuurist. Näiteks distants, mis ühes kultuuris on intiimse tähendusega, võib teises kultuuris kuuluda sotsiaalse suhtluse juurde (nt suudlemine) (Hall 1990: 118).

Ruumikasutus ja inimestevahelise distantsi suurus seostub otseselt kultuuriväärtustega (Samovar, Porter 2004: 190). Kõnesolevas uurimuses lähtuti Geert Hofstede (1980) kultuuridimensioonidest: individualism-kollektivism, maskuliinsus-feminiinsus, ebakindluse vältimise tarve ning võimudistants. Nende dimensioonidega on võimalik kirjeldada kõiki kultuure ja ühtlasi seletada ning prognoosida ka sarnasusi ja erinevusi kultuuridevahelises suhtluses (Gudykunst jt 1996: 21).

Individualismi-kollektivismi dimensioon iseloomustab rühma ja indiviidi vahelisi suhteid. Individualistlikes kultuurides on esmatähtsad üksikisiku huvid, soodustatakse eneseteostust ja eeldatakse, et inimesed hoolitsevad vaid iseenda ja oma lähedaste eest. Kollektivistlikes kultuurides seatakse esmatähtsaks rühma huvid. Rühm küll hoolib oma liikmetest, kuid vastutasuks nõuab lojaalsust (Gudykunst jt 1996: 22, Hofstede, Bond 1984: 419, Hofstede 2001: 226). Maskuliinsusdimensioon näitab maskuliinsete ja feminiinsete väärtuste kaalu ühiskonnas. Maskuliinsetes ühiskondades on soorollid kindlalt erinevad, tähtis on sõltumatus, ollakse orienteeritud rahale ja asjadele, tähtis on võim ja edasiliikumine. Feminiinsetes kultuurides pole soorollid fikseeritud, oluline on keskkond, elulaad ning suhted teiste inimestega (Gudykunst jt 1996: 47, Hofstede 2001: 297-299). Võimudistantsi dimensioon näitab suhteid erineva ühiskondliku ning varandusliku seisusega inimeste vahel: 
kuivõrd väikese võimuga institutsioonide ja organisatsioonide liikmed aktsepteerivad võimu ebavõrdset jaotumist ja selle autoritaarset kasutamist (Hofstede, Bond 1984: 419, Hofstede 2001: 98). Ebakindluse vältimise dimensioon vaatleb, kui ohtlikuks peab ühiskond ebakindlaid ja tundmatuid olukordi ning mil määral ta püüab neid kontrollida. Suure ebakindluse vältimise tarbega kultuurides arvatakse, et "kõik erinev on ohtlik", väikese ebakindluse vältimise tarbega kultuurides valitseb veendumus, et "kõik erinev on imelik" (Gudykunst jt 1996: 42, Hofstede 2001: 161).

Kuigi G. Hofstede algne uurimus (1980) ei hõlmanud Ida-Euroopa riike, on hilisemate uuringute tulemusel esitatud andmeid ka Eesti (Hofstede 2001) ja Leedu (Mockaitis 2002) kohta. Eesti ja Leedu kultuuridimensioonide näitajad on tabelis 1.

Tabel 1. Kultuuridimensioonide indeksid Eesti ja Leedu kohta (Mockaitis 2005: 46)

\begin{tabular}{|l|c|c|c|c|}
\hline & Individualism & Võimudistants & $\begin{array}{c}\text { Ebakindluse } \\
\text { tõrjumine }\end{array}$ & Maskuliinsus \\
\hline Leedu & 50 & 45 & 67 & 65 \\
\hline Eesti & 60 & 40 & 60 & 30 \\
\hline $\begin{array}{l}\text { Hofstede (2001) } \\
\text { andmebaasi } \\
\text { kõrgeim indeks }\end{array}$ & 91 & 104 & 112 & 110 \\
\hline $\begin{array}{l}\text { Hofstede (2001) } \\
\text { andmebaasi } \\
\text { madalaim indeks }\end{array}$ & 6 & 11 & 8 & 5 \\
\hline
\end{tabular}

Tabelis 1 esitatud andmete põhjal võib eeldada, et eestlastega võrreldes on leedulased märgatavalt kollektivistlikumad ja maskuliinsemad ning mõnevõrra suurema võimudistantsiga ja ebakindluse vältimise tarbega. Samas pole teada, kas eesti ja leedu erinevad väärtushinnangud tähendavad ühtlasi erinevusi vastavate maade vestluskäitumises. Käesolevas uurimuses soovitaksegi E. T. Halli ja G. Hofstede uurimustele toetudes teada saada:

1) milline on eestlaste ruumikäitumine ja kas see on kaheksa aasta jooksul muutunud;

2) milline on leedulaste ruumikäitumine võrreldes eestlastega.

\section{Materjal ja meetod}

Uuring koosnes kahest etapist. Eestlaste kohta viidi esimene ruumiuurimus läbi 1998. aastal (Altrov 1999). Tol korral oli küsitletavaid 40. Teine eestlaste ruumiuurimus viidi läbi 2006. aastal. Seekord oli küsitletavaid 30. Leedulasi küsitleti samuti 2006. aastal - vastanuid oli 27. Kõik uuringus osalejad olid kontoritöötajad, nende vanus oli $25-45$ eluaastat ning neil oli vähemalt viieaastane töökogemus. Nii eesti kui ka leedu rahvusest küsitletavate seas oli naisi ja mehi enam-vähem võrdselt. Naiste ja meeste tulemuste eraldi kajastamist ei peeta uuringus vajalikuks, kuna märkimisväärset erinevust vastustest ei ilmnenud.

Eestlaste ja leedulaste ruumikäitumist uuriti küsitluse teel. Küsitlus koosnes 12 valikvastusega situatsioonikirjeldusest. Küsitletava ülesanne oli neljast vastu- 
sevariandist valida üks tema jaoks sobivaim. Situatsiooniküsimused olid jagatud kolme rühma: kodune keskkond, töökeskkond ning suhted väljaspool kodu ja tööd. Nii situatsioonikirjeldused kui ka nende vastusevariandid tuginesid E. T. Halli (1990) ja G. Hofstede (1980) kultuuriuuringutele, autori isiklikule kogemusele ja vaatlustele.

Küsitlusvorm töötati välja 1998. aastal. Küsitlust muuta ja kaasajastada ei peetud 1998. aasta ja 2006. aasta andmete võrreldavuse huvides otstarbekaks.

\section{Küsitlus: situatsioonid, variandid ja tulemused}

Küsitlus koosnes situatsiooniküsimustest, mis olid jagatud kolme rühma: sooviti teada, millised on eestlaste ja leedulaste ruumi- ja distantsieelistused koduses keskkonnas, töösuhetes ning väljaspool kodu ja tööd aega veetes ning millistest kultuuritunnustest antud suhtlusolukorrad johtuvad.

\section{Koduga seotud küsimused}

Kodust keskkonda uuriti situatsioonide kaupa. Sooviti teada saada, kas küsitletavad soovivad privaatsust ka oma pereliikmetega suheldes, kas peetakse tähtsaks eraldatust naabritest, millisel määral väärtustatakse elukeskkonda ja kas kodus eelistatakse kindlaid distantsinorme, millega rõhutatakse suhtlemise formaalsust, või on suhtlemine vaba ja inimesekeskne.

\section{Esimene situatsioon}

Esimese situatsiooniküsimusega uuriti, kui oluline on küsitletava jaoks privaatsus oma perekonnas, naabritest eraldatuse soov, või vastupidi, seotus kaasinimestega.

Ühel hetkel märkad, et Sinu pereliikmete arv on tublisti kasvanud. Otsustad oma väikese äärelinna korteri parema vastu vahetada. Mille soetad?
A. Väikese maja äärelinnas (püüame sïski ära mahtuda), kuid suure iluaiaga.
B. Suure maja äärelinnas (kõik saavad oma toa), kuid aed on väike ja päikesevaene.
C. Suurema äärelinna korteri (läheb pisut lahedamaks) ilusa põlispargi ääres.
D. Samaväärse korteri, kuid kesklinnas. Leiad, et kesklinnas on paremad võimalused ajaveetmiseks väljaspool kodu: käia huvialaringides, kinos, teatris, olla sõprade seltsis kohvikutes/baarides.

A-variandi valijatele on elukeskkond väga oluline. Kõnesolev variant võiks iseloomustada feminiinseid, kollektivistlikke kultuure. Feminiinsed ühiskonnad väärtustavad elukvaliteeti, hoolitakse teistest inimestest, suurt tähelepanu pööratakse elukeskkonnale (Hofstede 2001: 298, 306). Kollektivistlikke kultuure iseloomustavad 
tugevad peresidemed (Hofstede 2001: 236), omaette olekul ei ole sellist tähtsust nagu individualistlikes kultuurides (Gudykunst, Ting-Toomey 1988: 123).

B-variandi valijatele on tähtis omaette olemise võimalus. Selline variant võiks iseloomustada maskuliinseid, individualistlikke, distantsi hoidvaid kultuure. Maskuliinsetes kultuurides rõhutatakse enda ego. Perekonda peetakse küll oluliseks, kuid elukeskkonda ei väärtustata. Kui feminiinsetes kultuurides ollakse orienteeritud väikestele asjadele, siis maskuliinsetes kultuurides hinnatakse suuri silmapaistvaid asju (Hofstede 2001: 298-299, 306).

C-variandi valijatele on elukeskkond olulisem kui privaatsus. Selline variant võiks iseloomustada feminiinseid, kollektivistlikke kultuure. Feminiinsetes kultuurides on olulised suhted teiste inimestega, sh võõrastega (Hofstede 2001: 299). Samuti hinnatakse feminiinsetes kultuurides kõrgelt elukeskkonda ja -kvaliteeti (Hofstede 2001: 298-299). Kollektivistlikkusele viitab asjaolu, et puudub privaatsuse nõue (Gudykunst, Ting-Toomey 1988: 123).

D-variandi valijad korvavad kodust ruumikitsikust seltsieluga väljaspool kodu. Antud variant võib viidata individualistlikule ja maskuliinsele kultuurile. Individualistlikes ja maskuliinsetes kultuurides tähtsustatakse peamiselt iseenda ja oma pere vajadusi ning kodu ongi eeskätt oma perekonna jaoks (Hofstede 2001: 227, 306). Maskuliinsetele väärtustele viitab ka asjaolu, et eluaseme valikul peetakse oluliseks selle prestiižset asukohta (Hofstede 2001: 312).

Esimese situatsiooni vastused on joonisel 1.

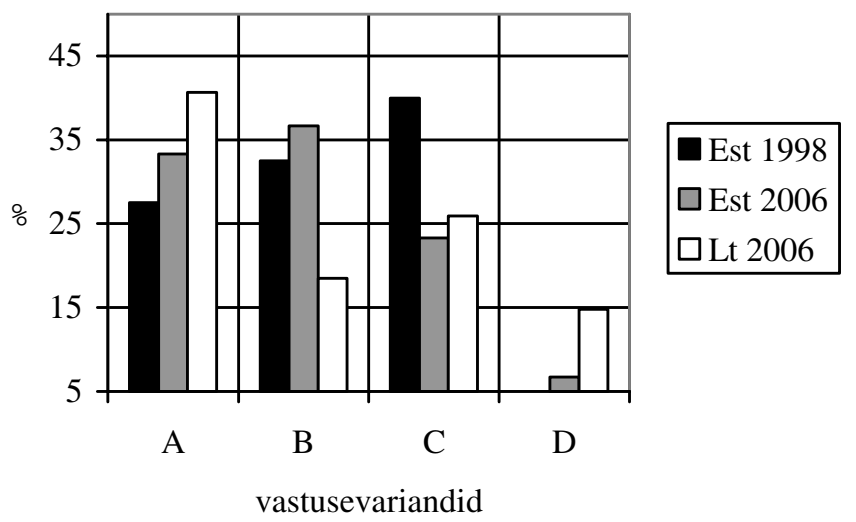

Joonis 1. Esimese situatsiooniküsimuse vastused

1998. aastal toetusid eestlaste eelistused peamiselt feminiinsetele kollektivistlikele väärtustele $(\mathrm{A}+\mathrm{C})$ : suhteliselt väike ruumivajadus, ilus elukeskkond. Ent esile tõuseb ka vastaspoolus, kuigi mitte domineerivana: suur maja, pereliikmete eraldumisvõimalus, ükskõiksus keskkonna suhtes (B), näidates individualistlike ja maskuliinsete väärtuste olemasolu kultuuris.

2006. aastaks polariseeruvad väärtushinnangud veelgi: suurenenud on nii suure maja eelistajate (B) kui ka keskkonna eelistajate hulk $(\mathrm{A}+\mathrm{C})$.

Võrreldes leedulasi eestlastega, on näha leedulaste elukeskkonna eelistus ning pühendumine inimsuhetele $(A+C)$, seega tuginevad leedulaste eelistused feminiinsetele kollektivistlikele väärtustele. 
Suhtlemisvõimalus linnakeskkonnas (D) jäi kõige vähem valitud variandiks nii eestlastel kui ka leedulastel.

\section{Teine situatsioon}

Teise situatsiooniga sooviti teada saada, kui suur on vastanute isikliku ruumi vajadus ja kas soovitakse eralduda võõrastest või ka oma pere liikmetest.

Ostsid endale just uue eluaseme. Mida seal esmajoones ette võtad?
A. Jagad ruumid pereliikmete vahel ära.
B. Paned akna ette läbipaistmatud kardinad, et naabrid sisse ei näeks.
C. Lähed tutvud naabrite ning ümbruskonnaga.
D. Lased osa vaheseinu maha lõhkuda, et tekiks avatud ruum.

A-variandi valijaid iseloomustab tugev individualism. Soovitakse eralduda ka oma perekonnas. Individualistlikes kultuurides on privaatsusel suur tähtsus (Gudykunst, Ting-Toomey 1988: 121, 123).

B-variandi valijatele on võõrastest eraldumine olulisem kui distants omas perekonnas. Selline suhtumine võiks olla ebakindlust halvasti taluva kultuuri peegeldus, kuna ebakindlust halvasti taluvates kultuurides hoitakse võõraga distantsi (Hofstede 2001: 161, 180).

$\mathrm{C}$-variandi valijatele on tähtsad elukeskkond ning inimsuhted. Selline variant võiks iseloomustada feminiinseid, kollektivistlikke ja ebakindlust hästi taluvaid kultuure. Feminiinsetes kultuurides on oluline elukeskkond, hoolitakse teistest inimestest ja inimsuhetest (Hofstede 2001: 298-299, 306). Kollektivistlikes kultuurides tähtsustatakse inimsuhteid, sotsiaalset võrgustikku ning naabruskonda (Hofstede 2001: 226-227). Ebakindlust taluvates kultuurides pööratakse tähelepanu suhetele ja tuntakse huvi võõra vastu (Hofstede 2001: 161, 170).

D-variandi valijaid iseloomustab kollektivistlikkus. Kollektivistlikus kultuuris on tähtsad suhted kaasinimestega, meie-tunne ning distantsihoidmist ei peeta oluliseks (Hofstede 2001: 226-227, 236, Gudykunst, Ting-Toomey 1988: 123).

Küsimusele antud vastused on esitatud joonisel 2.

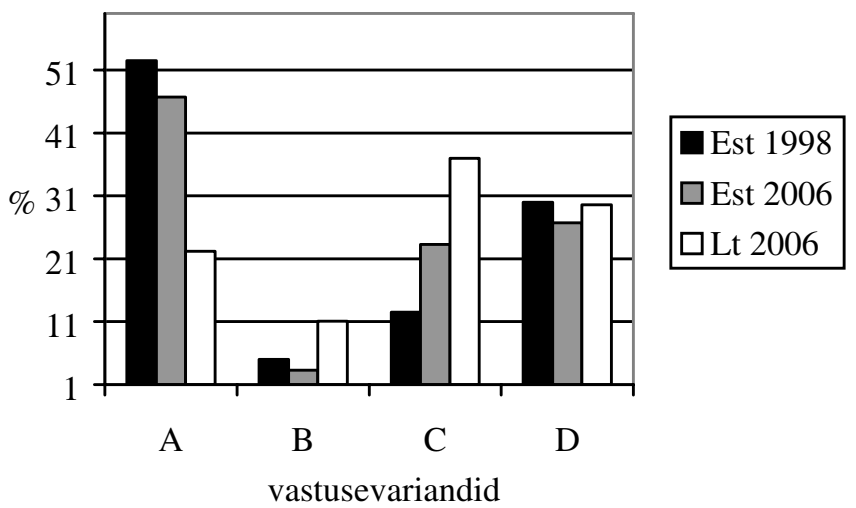

Joonis 2. Teise situatsiooniküsimuse vastused 
Eestlased on mõlemas küsitluses eelistanud A-varianti: jagada uude korterisse või majja elama asudes esmalt toad pereliikmete vahel ära. See on märk individualistlike väärtuste domineerimisest. Ent eestlastest eelistavad suhteliselt paljud ka avatud ruumi (D), mis soosib pereliikmete koosolemist ja omavahelist suhtlemist, kandes seega kollektivistlikke väärtusi.

Võrreldes esimese küsitlusega on märkimisväärselt tõusnud ka C-variandi eelistajate arv, kes uude elukohta asudes tutvuvad esmajoones sealse elukeskkonna ning naabritega. Nii nagu D-variant viitab see kollektivistlikele väärtustele, ent elukeskkonna tähtsustamine tõstab esile ka feminiinsed väärtused.

Kui C- ja D-variant kokku võtta, siis võib öelda, et individualistlike ja kollektivistlike väärtuste kandjaid on enam-vähem võrdselt, nagu ka eelmise situatsiooni puhul.

Võrreldes leedulasi eestlastega, on näha leedulaste ülekaalukas C-ja D-variandi eelistus. Seega iseloomustab leedulasi enim teistest inimestest ning keskkonnast hoolimine, samuti ka uudishimu võõra vastu.

Kõige vähem valituks osutus nii eestlaste kui ka leedulaste puhul B-variant eraldumine kardinate taha. Sellest võib järeldada, et ebakindlamaid olukordi koduses ruumikasutuses talutakse mõlemas kultuuris suhteliselt hästi.

\section{Kolmas situatsioon}

Selle situatsiooniküsimusega sooviti teada saada, kas vastanud seavad ruumikasutuses iseenda ja teiste vahele kindlad piirid ning kuidas suhtutakse ruumikasutusreeglite rikkumisse.

Kuidas sisustad elutoa?
A. Kerge konstruktsiooniga hõlpsasti liigutatava mööbliga.
B. Massïuse kalli mööbliga, mille sead paika aastateks.
C. Nimeka disaineri loodud mööbliga.
D. Kuidas juhtub, ja mis mööbel käepärast on.

A-variandi valijatele ei ole stabiilsus kuigi oluline. Ruumisviibijatel lastakse distantsi reguleerida oma soovi ja tujude kohaselt. Selline tunnus on iseloomulik ebakindlust hästi taluvatele kultuuridele, kus käitumist määravad vähesed reeglid ning sallitakse ka muutusi ja ebaselgust ning ollakse orienteeritud inimsuhetele (Hofstede 2001: 161, 170). Antud vastusevariant viitab ka feminiinse kultuuri joontele, kuna hinnatakse inimestekesksust ja vastastikuseid suhteid (Gudykunst jt 1996: 47, Hofstede 2001: 299).

B-variandi valijad hindavad stabiilsust. Stabiilsusega soovitakse tõrjuda ebakindlust. Ruumi sisustaja kehtestab distantsireeglid (paneb toolide kaugused paika, valib laua suuruse jne). Ebakindlust halvasti taluvates kultuurides tekitavad ebakindlad olukorrad ohutunde, mistõttu neis on palju käitumist suunavaid reegleid ja teistsugune käitumine ei ole lubatud (Gudykunst jt 1996: 42, Hofstede 2001: 166, 169). Vastusevariant viitab ka maskuliinse kultuuri tunnustele, kuna maskuliinsetes kultuurides eelistatakse suuri asju ja pereliikmete erivajadustele tähelepanu ei pöörata (Hofstede 2001: 299, 306, 312). 
C-variandi valijad ei kasuta distantsireguleerijana mööblit. Mööblil on nende jaoks muud funktsioonid. Ruumikorraldusest olulisem on mööbli väline hiilgus ja positsiooninäitamine. Iseloomulik on niisugune valik suure võimudistantsiga maskuliinsele kultuurile, kus pereliikmete vajadused jäetakse tagaplaanile ja tähtsad on raha ning asjad (Hofstede 2001: 299, 306).

D-variandi valijad ei kasuta või ei oska kasutada mööblit distantsireguleerijana. Mööblil pole muid funktsioone kui vaid olla mööbel.

Küsimusele antud vastused on esitatud joonisel 3 .

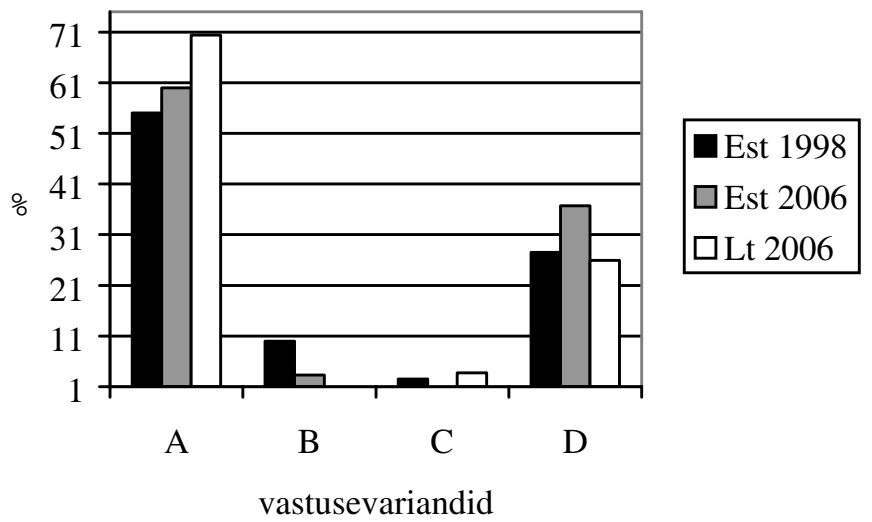

Joonis 3. Kolmanda situatsiooniküsimuse vastused

Nii 1998. kui ka 2006. aasta eestlaste ning leedulaste vastustes domineeris kerge ja hõlpsasti liigutatava mööbli eelistus (A), mis näitab, et peresuhetes ei soovita ruumisviibijatele fikseeritud distantse peale suruda. Seega tulid esile feminiinsele ja ebakindlust hästi taluvale kultuurile omased jooned: kodus keskendutakse inimestele, tähtsustatakse vastastikuseid suhteid ja suhtlemise mugavust ning ollakse valmis muutusteks. Suhteliselt suur hulk vastanuid aga ei pööra mööblivalikule tähelepanu (D), mis näitab, et ei teadvustata mööbli võimalusi suhtluse reguleerijana.

\section{Tööga seotud küsimused}

Töösuhteid uuriti situatsioonide kaupa. Sooviti teada saada, kas töökeskkonnas tähtsustatakse füüsilist privaatsust või saadakse privaatsustunne muul viisil, näiteks pilgukontakti vältimisest ja rääkimise lõpetamisest. Ühtlasi sooviti välja selgitada, kas vastanud hindavad töökeskkonnas inimsuhteid või peavad nendest olulisemaks tööülesandeid. Samuti taheti teada saada, kuidas küsitletavad tõlgendavad puudutamist - kas puudutamine kuulub vestluskäitumise juurde või peetakse seda distantsinormide rikkumiseks.

\section{Neljas situatsioon}

Selle situatsiooniküsimusega uuriti, kas vastanud eelistavad visuaalset või füüsilist privaatsust, või eelistavad pigem olla teistega koos ning suhelda. 
Suundud esimest päeva uuele töökohale. Tööruumi võid endale valida sääraste variantide seast:
A. Suur saal, mis on jaotatud lahtriteks.
B. Kabinet neljale, kus igal töötajal on omaette privaatne lahter.
C. Kabinet neljale, kus istutakse näod vastakuti.
D. Privaatne kabinet.

A-variandi valijad suhtlevad ise aktiivselt ning ootavad aktiivset suhtlemist ka teistelt. Selline variant iseloomustab eelkõige kollektivistlikke kultuure, kus rahavastiku tihedus ei võimalda otsest eraldumist ja omaetteolemist. Sellises kultuuris on piir privaatse ja sotsiaalse distantsivööndi vahel ähmane (Gudykunst, Ting-Toomey 1988: 123-128).

B-variandi valijad ei sea esmatähtsaks füüsilist privaatsust. Privaatsust on võimalik saavutada ka visuaalsest kontaktist hoidumisega (Hall 1990: 133-134). Kuna variandis kirjeldatud ruumikorralduse puhul on kolleegidel omavahel tõhusam töötada, siis iseloomustab see variant maskuliinset kultuuri (ollakse orienteeritud tööülesannetele ning tulemustele) (Hofstede: 2001: 298-299).

C-variandi valijaid iseloomustab soov üksteisega suhelda ning olla visuaalses kontaktis. Kuna inimesed ja suhted on tähtsad, iseloomustab variant feminiinseid kultuure (Hofstede 2001: 299). Kui soovitakse olla omaette, siis eraldutakse olemasolevas ruumis, s.t lõpetatakse rääkimine (vt Hall 1990: 140, 159).

D-variandi valijad tajuvad ruumi kui isiklikku sfääri ning enda ego laiendust. Selline valik iseloomustab sügavalt individualistlikku kultuuri (Hall 1990: 133, Hofstede 2001: 227).

Küsimusele antud vastused on esitatud joonisel 4 .

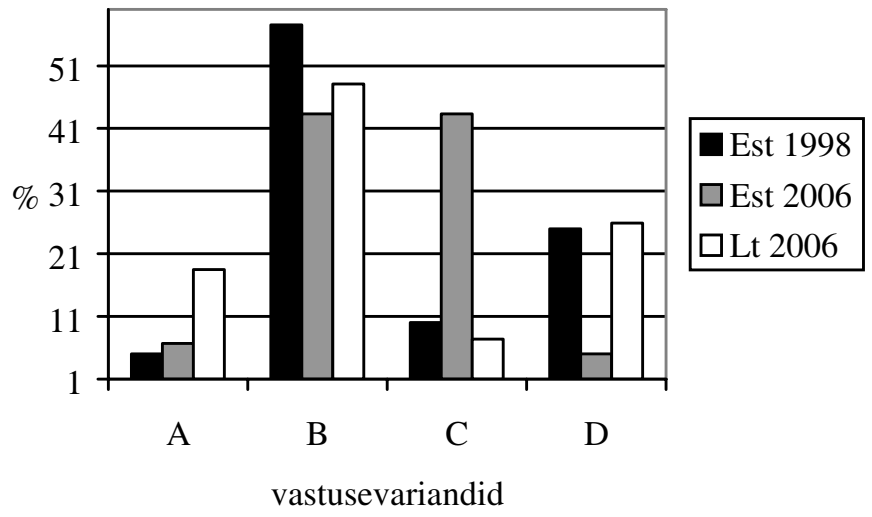

Joonis 4. Neljanda situatsiooniküsimuse vastused

1998. aastal eelistasid eestlased ülekaalukalt tööruumina kabinetti neljale, mis on jaotatud privaatseteks lahtriteks (B). Sellise valiku puhul ei peeta esmaseks füüsilist privaatsust, vaid piisab visuaalse kontakti vältimisest. Suhteliselt paljud vastanud soovisid aga töökeskkonnas kolleegidest füüsiliselt eralduda ja eelistasid töötada privaatses kabinetis (D). Seega tulid esile individualistlikule ja maskuliinsele 
kultuurile omased tunnused, kus inimsuhetest olulisemaks peetakse eraldatust, tööülesandeid ja -tulemuslikkust.

2006. aastal eelistasid eestlased samuti töötada nelja kolleegiga ühes kabinetis, kus igal töötajal on oma privaatne lahter (B), ent samavõrra sooviti töötada nelja kaastöötajaga tööruumis, kus istutakse näod vastakuti (C). Seega, erinevalt varasemast küsitlusest on oluliseks muutunud ka vastastikune seotus ja suhted kaastöötajatega: näeme liikumist maskuliinsetelt väärtustelt feminiinsetele.

Võrreldes leedulaste ja eestlaste vastuseid, sarnanesid leedulaste valikud eestlaste vastustega 1998. aastal: kõige enam sooviti jagada tööruumi nelja kolleegiga, kusjuures igaühel oleks oma privaatne lahter (B). Samuti eelistasid paljud vastanud eralduda kaastöötajatest ning töötada privaatses kabinetis (D). Nii B- kui D-variant näitab, et töökeskkonnas peetakse inimsuhetest olulisemaks keskendumist tööülesannetele, see on aga maskuliinse kultuuri tunnus.

\section{Viies situatsioon}

Kultuure saab jagada avatud ja suletud ustega kultuurideks (vt Hall 1990: 134, 138-139). See tähendab, ühtedes kultuurides hoitakse uksi suletuna, teistes jällegi hoitakse uksi lahti. Ka on suletud või avatud uksel kultuuriti erinev tähendus, nt Saksamaal ei tähenda suletud uks, et inimene soovib olla segamatult omaette või on teoksil midagi, mida ei taheta teistele näidata, vaid suletud uksega säilitatakse ruumi terviklikkus ja luuakse töötamiseks vajalik keskkond (Hall 1990: 135-136). Põhjaameeriklastele seevastu on kinnine uks nõupidamiste, eravestluste ja tegevuste jaoks, mida ei taheta teistele näidata, ja suhtlema ollakse valmis siis, kui uks on avatud (Hall 1990: 138-139).

Viienda küsimusega sooviti teada, kas eestlased ja leedulased on suletud või avatud uste eelistajad.

Töötad läbikäidavas kontoriruumis. Tagaruumitöötajad tõmbavad oma tuppa minnes enda järel aegajalt ukse kinni. Kuidas suhtud ukse sulgemisse?

A. Arvad, et Sind püütakse kõrvale tõrjuda või tahetakse Sinu eest midagi varjata.

B. Lükkad ukse lahti, et tagaruumitöötajatega seotust säilitada.

C. Suletud ukse taga tunned end turvaliselt ja saad paremini tööle keskenduda. Kui tagaruumitöötajad jätavad ukse lahti, siis suled selle ise.

D. Ei pööra sellistele pisiasjadele tähelepanu.

A-variant osutab avatud ustega kultuurile, ja ka ebakindlust vältivale kultuurile: suhtes ei sallita ebaselgust (Hofstede 2001: 161).

B-variant osutab avatud ustega kultuurile ja ka kollektivistlikule kultuurile: tahetakse olla seotud teiste inimestega (Hofstede 2001: 227).

C-variant osutab suletud ustega kultuurile ja ka individualistlikule kultuurile: soovitakse privaatsust ja austatakse üksiolemise õigust (Hall 1990: 133, Hofstede 2001: 227). Ukse sulgemisega luuakse distants iseenda ja väljaspool ruumi olijate vahel. 
D-variandi valijate jaoks ei ole ukse sulgemine või avamine suhete reguleerimisvahend, ühtlasi näitab see, et ümbruses toimuvale ei pöörata suurt tähelepanu. Inimsuhete asemel ollakse orienteeritud tööülesannetele, mis on iseloomulik maskuliinsele kultuurile (Hofstede 2001: 298, 318).

Küsimusele antud vastused on esitatud joonisel 5 .

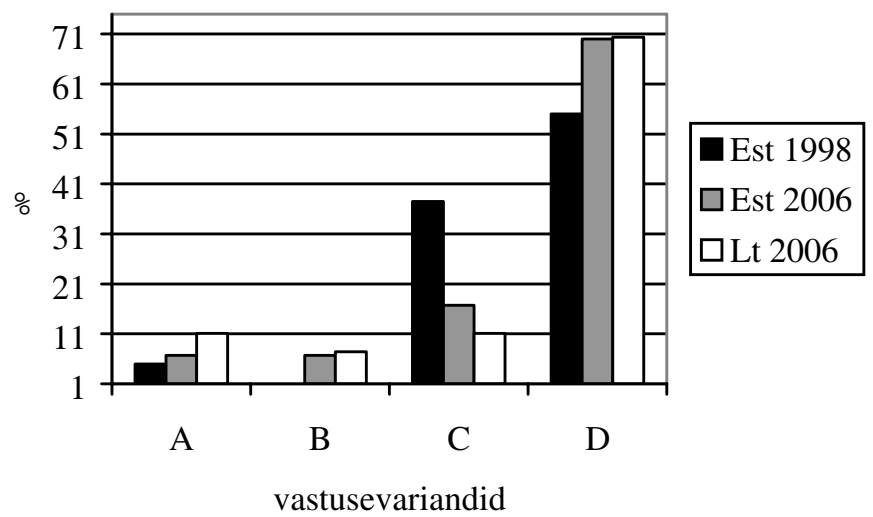

Joonis 5. Viiendale situatsioonile antud vastused

Selle situatsiooni puhul olid eestlaste ja leedulaste küsitluse vastused sarnased: vastanud ei pööra tähelepanu, kas nende tööruumi uks on lahti või kinni (D). Seega ei saa kumbagi kultuuri liigitada ei suletud ega avatud ustega kultuuriks. D-variandi valik viitab maskuliinse kultuuri väärtustele, kuna ollakse orienteeritud töösuhetele. Samas võib D-variandi eelistus viidata ka asjaolule, et küsitletavad ei pruugi olla teadvustanud endale ukse kui suhtlusreguleerija funktsiooni.

Eestlaste kahanev vajadus ust sulgeda (vt C-variant) näitab, et privaatsust ei peeta enam nii oluliseks kui varasemas küsitluses.

\section{Kuues situatsioon}

Kuuenda situatsiooniküsimusega sooviti teada, milline tähtsus on füüsilise privaatsuse kõrval visuaalsel privaatsusel ja kas küsitletavad järgivad selles osas n-ö sakslaste mudelit, mille korral visuaalse kontaktiga ületatakse privaatse tsooni piir (vt Hall 1990: 133-134).

Jagad kabinetti kolleegiga. Sisse astub töökaaslase tuttav ja hakkab ilma Sind tähele panemata oma tuttavaga vestlema. Kuidas suhtud?

A. Oled rahul, et Sind ei häirita - saad segamatult töötada.

B. Leiad, et Sinust on mööda mindud, tunned end puudutatuna.

C. Sul ükskõik, kes sisse astub või väljub ja kas Sinuga suheldakse või mitte.

D. Sekkud ka ise vestlusesse. 
A-variandi korral aktsepteeritakse visuaalset privaatsust ning negatiivset viisakust: teine inimene jäetakse rahule, luuakse distants ja austatakse üksiolemisõigust. Tegemist on maskuliinse kultuuriga: tähtis on tulemus, edasiliikumine, ollakse orienteeritud tööülesannetele (Hofstede 2001: 298-299).

B-variandi valijad pööravad suurt tähelepanu inimsuhetele, vastandatakse "meie" ja "nemad", visuaalset privaatsust ei tunnistata. Selline käitumine on iseloomulik kollektivistlikule kultuurile (Hofstede 2001: 226-227).

C-variant näitab, et suhteid teiste inimestega peetakse ebaoluliseks ja ümbruses toimuvale ei pöörata tähelepanu. Tegemist võib olla maskuliinse kultuuriga, kus eelistatakse keskenduda tööle, mitte suhtlemisele (Hofstede 2001: 298-299).

D-variandi valijate jaoks on oluline seotus ja suhted teiste inimestega. Privaatsust, sealhulgas visuaalset privaatsust ei vajata. Selline tunnus võib iseloomustada kollektivistlikke ja feminiinseid kultuure (Gudykunst, Ting-Toomey 1988: 123, Hofstede 2001: 299).

Küsimusele antud vastused on esitatud joonisel 6.

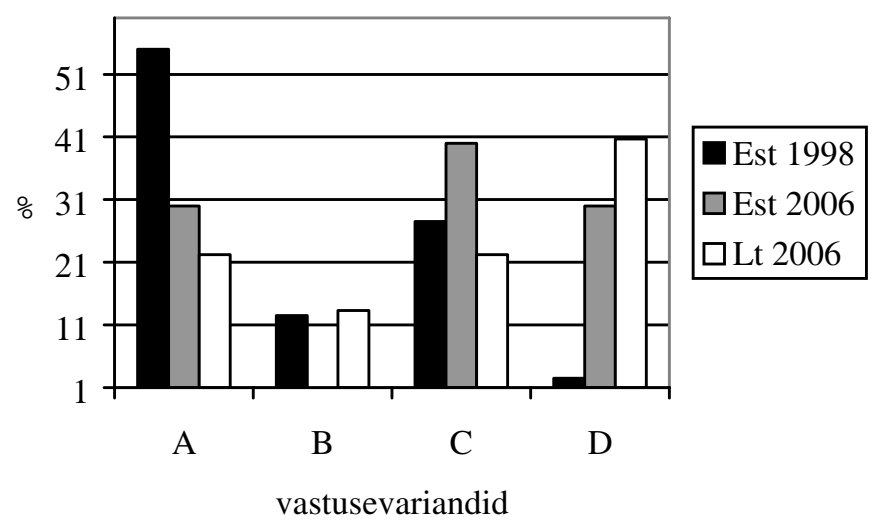

Joonis 6. Kuuendale situatsioonile antud vastused

Eestlased eelistasid 1998. aasta küsitluses A-varianti: nad on rahul, et töökeskkonnas neid ei häirita ja nad saavad tööle keskenduda. 2006. aastal oli A-variandi osakaal vastustes vähenenud ja eelistati C-varianti: teistega suhtlemisele ei pöörata tähelepanu. Nii A- kui C-variant iseloomustavad maskuliinset kultuuri, kus peatähelepanu on tööülesannetel ja nende tulemuslikkusel. Mõlemad variandid näitavad, et eestlased ei pea füüsilist eraldatust efektiivse töötamise jaoks ainuvõimalikuks lahenduseks, piisab ka visuaalsest kontaktist hoidumisest.

Erinevalt 1998. aastast oli 2006. aastal mh suur osa vastanuid, kelle jaoks olid tööülesannetest ja privaatsusest olulisemad suhted kaastöötajatega (D). Seega ilmnevad kultuuris ka feminiinsed ja kollektivistlikud tunnused.

Võrreldes eestlasi ja leedulasi, eelistasid leedulased vestlusesse sekkuda (D), mis tähendab, et suhteid ja vastastikust seotust kaastöötajatega peetakse oluliseks. Seega on tegemist feminiinsele ja kollektivistlikule kultuurile omaste tunnusjoontega. Samas oli suur hulk neid vastanuid, kes eestlastega sarnaselt ei pööra ümbritsevale tähelepanu ja on keskendunud tööle (A ja C), mis viitab maskuliinse kultuuri väärtustele. 
Seitsmenda situatsiooniga sooviti teada saada, kas eestlased ja leedulased kasutavad sarnaselt inglastega distantsireguleerijana ka häälevaljust (vt Hall 1990: 142).

Kolleegiga kahekesi olles jutustad talle oma nädalalõpust, mille veetsid koos oma sõbra või sõbratariga. Äkki märkad, et ruumis on veel keegi. Kuidas reageerid?
A. Katkestad jutu ning lubad kolleegile, et räägid hiljem edasi.
B. Tasandad häält ning jutustad loo lõpuni.
C. Ei lase ennast kolmandast ruumisolijast häirida ning jätkad valjuhääl- selt muljete jagamist.
D. Kaasad vestlusesse ka kolmandajuuresolija.

A-variandi valijaid iseloomustab vajadus säilitada privaatsus. Selline käitumine on omane eeskätt individualistlikule distantsi hoidvale kultuurile (Gudykunst, TingToomey 1988: 123-124, Hofstede 2001: 227).

B-variandi valijad püüavad end teistest eraldada hääletugevust vähendades. Nii luuakse enda ümber privaatne tsoon ning antakse märku, et sissetungija pole oodatud (Hall 1990: 142). Enamasti on sellisel puhul tegemist individualistliku maskuliinsusesse kalduva kultuuriga (Gudykunst, Ting-Toomey 1988: 123124).

C-variandi valijate jaoks on piir personaalse ning sotsiaalse ruumi vahel ähmane (vt Hall 1990: 154jj). Selline valik näitab, et tegemist võib olla kollektivistliku feminiinse kultuuriga (Hofstede 2001: 227, 298). Samas võib hääle mittetasandamine tähendada ka avatuse demonstreerimist (vt Hall 1990: 142).

D-variandi valijad seavad esikohale inimsuhted. Selline käitumine on oodatav kollektivistlikus või siis feminiinses kultuuris, kus hinnatakse positiivset viisakust - teisele inimesele tähelepanu pööramist, tema kaasamist suhtlusesse (Hofstede 2001: 227, 298).

Küsimusele antud vastused on esitatud joonisel 7 .

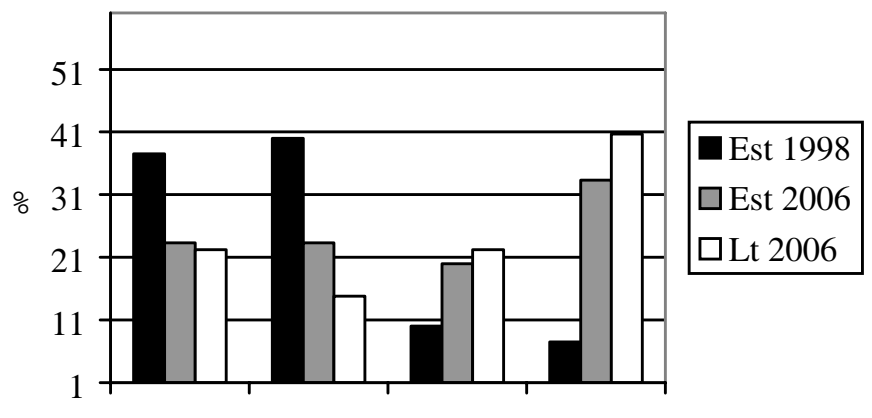

A $\quad$ B $\quad$ C $\quad$ D

vastusevariandid

Joonis 7. Seitsmenda situatsiooniküsimuse vastused 
Eestlaste 1998. aasta vastustes domineerisid A- ja B-variant, mis viitab asjaolule, et eestlased kasutavad distantsireguleerijana häälevaljust ning peavad eraldatust oluliseks. Selline valik osutab individualistliku ja maskuliinse kultuuri tunnustele. Samuti püütakse teist inimest mitte häirida ja soovitakse, et asjassepühendamatu vestlusesse ei sekkuks.

Eestlaste 2006. aasta vastustes on ülekaalus D-variandi valijad, mis vastupidiselt 1998. aasta tulemustele viitab, et inimsuhetele pööratakse ka töökeskkonnas rohkem tähelepanu. Taoline valik viitab feminiinse kultuuri väärtuste esiletõusmisele ja positiivse viisakuse ilmnemisele kultuuris (teist inimest ei jäeta suhtlusest kõrvale).

Võrreldes eestlaste ja leedulaste vastuseid, on leedulaste valik sarnane eestlaste 2006. aasta küsitluse tulemustega - kolmas ruumisviibija kaasatakse vestlusesse. Seega iseloomustavad leedulasi feminiinsed väärtused - teistest inimestest hoolimine.

\section{Kaheksas situatsioon}

Kaheksanda situatsiooniküsimusega sooviti teada saada, kuidas vastanud suhtuvad vestluspartneri hingeõhu tundmisse - kas hingeõhu tundmine kuulub suhtluse juurde või peetakse seda ebameeldivaks ja ruumikitsikust tekitavaks (vt Hall 1990: 159-160, Samovar, Porter 2004: 186-187).

Rääkides on vestluspartner Sulle väga lähedale tulnud ja Sa tunned tema hingeõhku. Kuidas reageerid?
A. Oledväga häiritud: küsid, mida vestluspartner on söönud/joonud. Või- maluse korral pakud talle kurgupastille.
B. Tunned end ebamugavalt, kuid püüad seda mitte välja näidata, taganed tasapisi.
C. Sulle meeldib vestluspartneri hingeõhku tunda.
D. Ei pane antud asjaolu tähelegi.

A-variandi valijate jaoks on kindel distants vestluspartneriga väga oluline ning selle rikkumisse suhtutakse resoluutselt otsest suhtlusstiili kasutades. Selline käitumine ja kõnestiil iseloomustab eeskätt individualistlikke maskuliinseid kultuure (vt Gudykunst, Ting-Toomey 1988: 124, Gudykunst jt 1995: 325).

B-variandi valijad soovivad hoida distantsi, kuid samuti püütakse vältida konflikte, ebakindlaid olukordi talutakse A-variandiga võrreldes paremini. Selline valik võiks iseloomustada ebakindlust suhteliselt hästi taluvaid kultuure (emotsioonid hoitakse vaos) (Hofstede 2001: 160), kus ühtlasi aktsepteeritakse negatiivset viisakust.

C-variandi valijad pööravad suurt tähelepanu inimsuhetele, neile meeldib olla üksteise lähedal, piir intiimse ja personaalse tsooni vahel on ähmane (vt Hall 1990: 159-160). Enamasti iseloomustab selline valik kollektivistlikke ja feminiinseid kultuure (Gudykunst, Ting-Toomey 1988: 123-128, Samovar, Porter 2004: 186-187, 190).

D-variandi valijaid iseloomustab kas ebateadlikkus distantsireeglitest, või siis on distantsipiirid nende inimeste jaoks ähmased. Hingeõhu tundmist võetakse 
kui loomulikku asja, mis ei häiri (vt Hall 1990: 157-160, Samovar, Porter 2004: 186-187). Selline valik võiks iseloomustada kollektivistlikke kultuure (Gudykunst, Ting-Toomey 1988: 123-128, Hall 1990: 53).

Küsimusele antud vastused on esitatud joonisel 8.

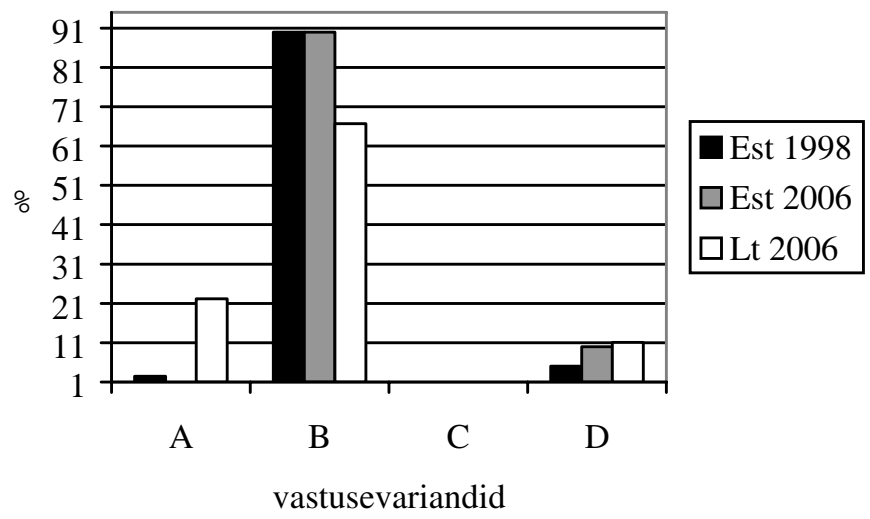

Joonis 8. Kaheksanda situatsiooniküsimuse vastused

B-variandi ülekaalukas valik (teise inimese hingeõhu tundmine on ebameeldiv, kuid seda püütakse mitte välja näidata), ja C-variandi mittevalimine (suhtluspartneri hingeõhu tundmine on meeldiv) eestlaste ja leedulaste seas näitab, et mõlemad kultuurid peavad distantsihoidmist sotsiaalses suhtluses vajalikuks, kuid distantsireegleid ei suruta inimesele peale otsesõnaliselt. Välditakse konflikte ja hoidutakse teise inimese ärritamisest. Samas on leedulaste hulgas ka neid vastanuid, kes pidasid ruuminormide rikkumist vastumeelseks ja seda otsesõnu ka väljendaksid (vt A-variant).

\section{Üheksas situatsioon}

Kultuure võib jagada ka kontakt- ja mittekontaktkultuurideks. Kontaktkultuurides tulevad inimesed üksteisele lähedale ning vestluse käigus puudutavad teineteist. Mittekontaktkultuurides on inimese isiklik ruum suur (Gudykunst, Ting-Toomey 1988: 124-126). Üheksanda situatsiooniküsimusega soovitigi teada, kuhu paigutuvad kontaktkultuuride-mittekontaktkultuuride dimensioonil eestlased ja leedulased.

Sinu ülemus on muhe mees. Tal on harjumus alluvatega vesteldes neile käsi õlale panna või siis seljale patsutada. Kuidas suhtud?

A. Sulle meeldib, et Sind "omaks poisiks" peetakse ja võtad seda kui tunnustust.

B. Pü̈̈ad ülemusele mõista anda, et Sulle säärane semutsemine ei meeldi.

C. Vastad samaga.

D. Sulle meeldib ülemuse heatahtlik suhtumine, mitte patsutamine. 
A-variandi korral talutakse füüsilist kontakti ning piir isikliku ja intiimse distantsivööndi vahel on ähmane (vt Hall 1990: 154-159). Nii käitutakse enamasti suure võimudistantsiga kultuurides, kus ideaalne ülemus on kui hea isa, kelle soosingut tahetakse võita. Tunnistatakse ülemuse eesõigusi (vt Gudykunst, Ting-Toomey 1988: 124-126, Hofstede 2001: 98, 107), sh distantsireeglitest üleastumist.

B-variandi valijad ei talu füüsilist kontakti ning ruumivööndite vahel tehakse vahet. Iseloomustada võiks selline suhtumine väikese võimudistantsiga individualistlikke kultuure, kus ei kardeta oma suhtumist välja näidata (Hofstede 2001: 107, 116).

C-variandi valijad on orienteeritud inimsuhetele - lähedust ei peljata. Variant iseloomustab väikese võimudistantsiga feminiinseid kultuure. Ülemused ja alluvad on seal võrdsed (Hofstede 2001: 107-108, 298-299). William Gudykunsti ja Stella Ting-Toomey järgi (1988: 128) ei ole väikese võimudistantsi, väikese ebakindluse vältimise tarbega ning feminiinsetes kultuurides reeglid puudutamise suhtes nii ranged kui suure võimudistantsiga, suure ebakindluse vältimise tarbega ja maskuliinsetes kultuurides.

D-variandi valijad ei talu füüsilist kontakti ega distantsipiiride rikkumist. Iseloomulik on selline suhtumine individualistlikele maskuliinsetele kultuuridele (Gudykunst, Ting-Toomey 1988: 127-128). Võimudistants sellises kultuuris ei saa olla väga väike (üksteist ei patsutata), kuid ei saa olla ka väga suur (patsutamine ei meeldi, seda ei võeta kui soosingu osutamist).

Küsimusele antud vastused on esitatud joonisel 9.

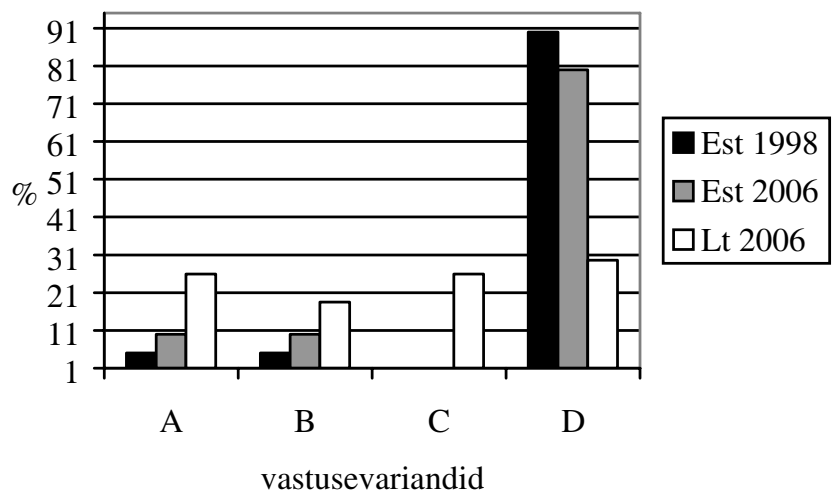

Joonis 9. Üheksanda situatsiooniküsimuse vastused

Eestlased on mõlemas küsitluses eelistanud D-varianti: ülemuse heatahtlik suhtumine meeldib, kuid taunitakse patsutamist. See osutab asjaolule, et eestlaste puhul on tegemist mittekontaktkultuuriga: inimesed ei talu füüsilist kontakti ega distantsipiiride rikkumist. Samuti viitab puudutamisest hoidumine individualistliku ja maskuliinse kultuuri väärtustele.

Leedulaste küsitluses ei domineerinud antud situatsiooniküsimuse puhul selgelt ükski vastusevariant. Osa vastanuid eelistas sarnaselt eestlastega D-varianti, mille puhul puudutamisest hoidumine viitab individualistliku ja maskuliinse kultuuri väärtustele. Samas oli palju ka neid vastanuid, kes võtsid ülemuse õlalepatsutust kui 
tunnustust (A), vastasid ise samaga (C) või kes püüdsid ülemusele mõista anda, et puudutamine on ebameeldiv (B). Kui A-variant osutab suure võimudistantsiga kultuurile, siis B- ja C-variant on vastupidiselt väikse võimudistantsiga kultuuri tunnus.

\section{Kümnes situatsioon}

E. T. Halli (1990: 122-123) järgi hoiavad inimesed mõjukate inimestega sotsiaalset distantsi (hoiavad üksteisest suhteliselt kaugele). Kümnenda situatsiooniküsimusega soovitigi teada, kuidas käituvad kõnesolevas situatsioonis eestlased ja leedulased.

Oled suure osakonna juhataja. Täna on peadirektori juures iganädalane osakonnajuhatajate koosolek. Kuhu istud?
A. Arvestad väljakujunenud kohtadegaja istud n-ö oma kohale.
B. Püüad istuda juhi kõrvale.
C. Istud direktorist võimalikult kaugele.
D. Ei tee kohast numbrit, istud, kuhu juhtub.

A-variandi puhul on koht ja inimene seotud. Selline valik iseloomustab ebakindlust halvasti taluvaid kultuure, kuna inimesi ahistab kõik ootamatu ja ebaselge (Hofstede 2001: 160-161).

B-variandi puhul võiks tegemist olla suure võimudistantsiga maskuliinse kultuuriga: kõrgemal positsioonil olevale isikule soovitakse meeldida, edukatele kuulub sümpaatia (Hofstede 2001: 98, 107-108, 299, 318).

$\mathrm{C}$-variandi valijaid iseloomustab lugupidav suhtumine ülemustesse. Iseloomulik on sellise variandi eelistamine suure võimudistantsiga kultuuris, kus ebavõrdsus on heakskiidetav ning alluvad ootavad käske ja korraldusi (Hofstede 2001: 98, 107-108).

D-variandi puhul puudub koha ja inimese vahel seos. Selline variant osutab ebakindlust hästi taluvale kultuurile (Hofstede 2001: 160-161).

Küsimusele antud vastused on esitatud joonisel 10.

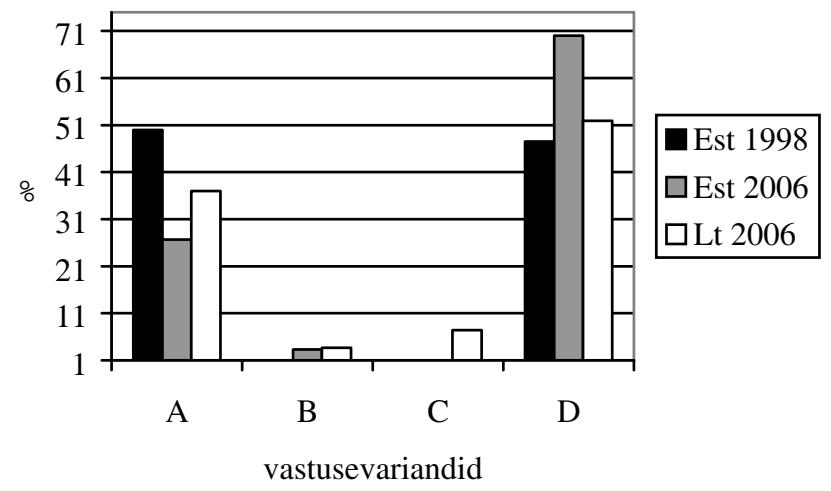

Joonis 10. Kümnenda situatsiooniküsimuse vastused 
1998. aastal jagunesid eestlaste vastused vastandlike A- ja D-variandi vahel: arvestatakse väljakujunenud kohtadega või valitakse istekoht juhuslikult. Kui A-variant viitab ebakindlust halvasti taluvale kultuurile, siis D-variandi valijad taluvad ebakindlaid olukordi hästi.

2006. aastal on eestlaste seas vähenenud A-variandi osakaal ja samavõrd on suurenenud D-variandi eelistus. Seega tõusevad vastustes enam esile ebakindlust hästi taluva kultuuri tunnused. B-variandi vähene ja C-variandi mittevalimine viitab väikesele võimudistantsile ja feminiinsetele väärtustele - ühiskonnas hinnatakse võrdsust ja sõltumatust. Võim seondub vaid erinevate rollide ja ametikohtadega, kuid need ei ole jäävad: tänane alluv võib olla homne ülemus, ja vastupidi (vt Hofstede 1993: 42-75).

Võrreldes leedulasi eestlastega, sarnanes leedulaste valik eestlaste mõlema küsitluse tulemustega: kuigi leedulaste vastustes domineeris D-variant (istekohast ei tehta numbrit ja istutakse kuhu juhtub), oli suur hulk neid vastanuid, kes eelistasid A-varianti (soovivad istuda n-ö oma kohale). Kui D-variant viitab ebakindlust hästi taluva kultuuri väärtustele, siis A-variant on ebakindlust halvasti taluva kultuuri tunnus.

\section{Vaba ajaga seotud küsimused}

Suhteid väljaspool kodu ja tööd uuriti situatsioonide kaupa. Sooviti teada saada, kas vastanud suhtlevad avalikus kohas meelsasti võõraste inimestega või keskenduvad vaba aega veetes eeskätt suhetele oma sõprade ja lähedastega. Ühtlasi taheti välja selgitada, kuidas suhtuvad eestlased ja leedulased ebaselgetesse ruumilistesse olukordadesse - kas ruuminormide rikkumise korral kasutatakse otsest või kaudset verbaalset stiili.

\section{Üheteistkümnes situatsioon}

Selle situatsiooniküsimusega uuriti, kuidas eestlased ja leedulased käsitavad personaalset tsooni avalikus kohas ja kui oluline on vastanute jaoks privaatsus vaba aega veetes - kas võõras inimene lubatakse seltskonda ja haaratakse vestlusesse või tõrjutakse ta kõrvale, ning kuidas seda tehakse.

Veedad sõbraga aega populaarses kohvikus. Teie lauas on kaks vaba kohta, kuid üksikuid vabu kohti on mujalgi. Üks kohvikukülastajatest palub luba teie lauda istuda. Kuidas käitud?
A. Ütled, et soovite omaette olla.
B. Lubad, kuid ise oled pahane, et just teie lauda tuldi. Õhtu on rikutud.
C. Palud istudaja kaasad ta peatselt vestlusesse.
D. Lubad, kuid käitud hiljem temaga nagu õhuga.

A-variandi valijad soovivad avalikus kohas privaatsust ning neid iseloomustab resoluutsus ja otsese verbaalse stiili kasutamine. Selline käitumine on iseloomulik individualistlikele maskuliinsetele kultuuridele (Salo-Lee jt 1996: 36-39). 
B-variandi valijad kasutavad kaudset verbaalset stiili - inimestel on raske öelda ei. Enamasti on selline stiil omane kollektivistlikele kultuuridele (Gudykunst jt 1996: 29-34). Tehakse vahet sotsiaalse ja isikliku ruumivööndi vahel (vt Hall 1990: 154-159).

C-variandi valijad peavad väga tähtsaks inimsuhteid ning üksteisest hoolimist. Suheldakse ise meeleldi ja oodatakse seda ka teistelt. Variant iseloomustab kollektivistlikke ja ka feminiinseid kultuure, kus hinnatakse positiivset viisakust (Hofstede 2001: 226-227, 298-299).

D-variandi valijad ei ole orienteeritud inimsuhetele. Tegemist võib olla individualistliku ning maskuliinse kultuuriga, kus hinnatakse negatiivset viisakust (Hofstede 2001: 227, 299).

Küsimusele antud vastused on esitatud joonisel 11.

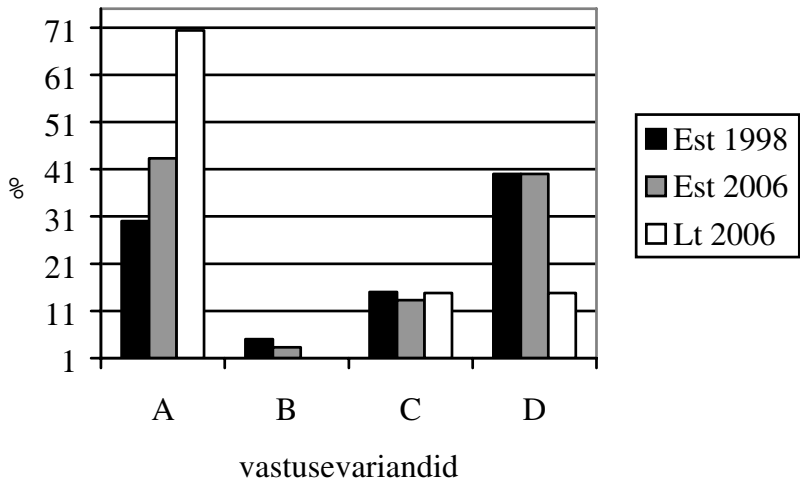

Joonis 11. Üheteistkümnenda situatsiooniküsimuse vastused

Selle situatsiooni puhul iseloomustasid eestlasi nii 1998. aastal kui 2006. aastal maskuliinsed ja individualistlikud väärtused - mõlemal juhul ei olnud eestlased valmis neile tundmatu inimesega suhtlema (A ja D). Samas, kui esimese küsitluse puhul aktsepteerisid vastanud negatiivset viisakust (võõras inimene lubatakse oma lauda, kuid teda vestlusesse ei kaasata), siis järgnevas uuringus oli nihe otsese suhtlusstiili kasutamise suunas (võõrale inimesele teatatakse otsekoheselt, et teda seltskonda ei soovita).

Leedulaste vastustes oli ülekaalus A-variandi valik, mis näitab, et eestlastest enam ollakse valmis oma personaalset ruumi ja privaatsust otsesõnu kaitsma. B-variandi (kaudne verbaalne stiil, raske anda eitavat vastust) mittevalimine ja D-variandi (hinnatakse teise inimese eraldumisõigust) vähene valik viitab, et leedulastele ei ole avalikus suhtluses omased kollektivistliku kultuuri tunnused ning nad hindavad võõrastega suheldes eestlastest märgatavalt vähem negatiivset viisakust. Seega toovad kõnesoleva küsimuse vastused leedulaste puhul esile individualistlikud maskuliinsed väärtused, kus domineerib otsene verbaalne stiil.

\section{Kaheteistkümnes situatsioon}

Sooviti teada saada, kuidas eestlased ja leedulased suhtuvad ruumiliselt ebaselgetesse suhtlussituatsioonidesse, kus kaasinimese kavatsused on teadmata, ja kas nad 
käituvad ruuminormide rikkumise korral aktiivselt ning agressiivselt või passiivselt ja taandudes (vt Gudykunst, Ting-Toomey 1988: 124).

Toidupoes leti juures seistes tajud, kuidas Sinu taga olev inimene Sulle järjest lähemale nihkub. Viimaks tunned kuklas juba tema hingeõhku! Kuidas reageerid?
A. Tunned hirmu ja püüad märkamatult eest ära liikuda.
B. Vihastud ning nõuad, et selgatükkija hoiaks "pikivahet".
C. Kuigi oled ärritunud, mõtled "Mina olin sïn enne" ja ei lase ennast kõrvale tõrjuda.
D. Ei pane antud asjaolu tähelegi.

A-variandi valijad ei salli ebaselgust. Kõik võõrastav tekitab ohutunde. Distantsipiiride rikkumisele reageeritakse passiivselt, taandudes. Iseloomulik on selline käitumine kollektivistlikele kultuuridele, kus ebakindluse vältimise tarve ei ole siiski kuigi suur. Sellises kultuuris ärritust otsesõnu ei väljendata (vt Gudykunst, Ting-Toomey 1988: 124, Gudykunst jt 1996: 42, Hofstede 2001: 160).

B-variandi valijad reageerivad ebaselgetes suhtlussituatsioonides resoluutselt otsest verbaalset stiili kasutades. Selline käitumine on iseloomulik individualistliku, maskuliinse kultuuritaustaga ja suure ebakindluse vältimise tarbega inimestele (Gudykunst, Ting-Toomey 1988: 124, Gudykunst jt 1995: 325, Hofstede 2001: 160).

C-variandi valijad ei kasuta ebaselgetes olukordades otsest verbaalset stiili, kuid samas väljendatakse kehakeelega oma suhtumist ning ei lasta end võõral inimesel kõrvale tõrjuda. Säärast käitumist võib oodata individualistlikes maskuliinsetes kultuurides (Gudykunst, Ting-Toomey 1988: 124, 128). Tõenäoliselt taluvad antud vastusevariandi eelistajad B-variandi valijatega võrreldes suhteliselt paremini ka ebakindlust, kuna ärritust ja viha otseselt ei väljendata (Hofstede 2001: 160).

D-variandi valijad ei hooli järjekordades seismisest: neile meeldib olla üksteise lähedal ja suhelda. Omane on selline valik kollektivistlikele kultuuridele (vt Hall 1990: 154-157, 162).

Küsimusele antud vastused on esitatud joonisel 12.

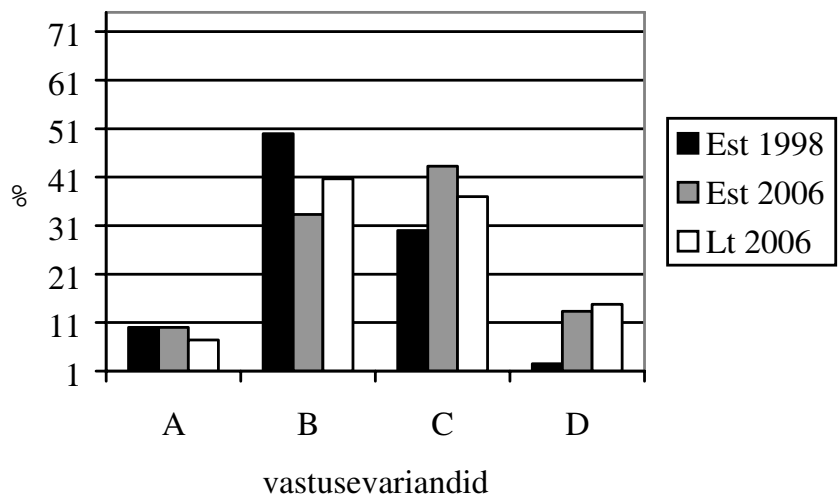

Joonis 12. Kaheteistkümnenda situatsiooniküsimuse vastused 
Selle situatsiooni puhul olid eestlaste ja leedulaste tulemused suuremas osas sarnased, s.t kumbki kultuur ei talunud ruumiliselt ebaselgeid olukordi. A- ja D-variandi (omane kollektivistlikele kultuuridele) vähene valimine ning B-ja C-variandi (privaatsus oluline) eelistamine viitab, et eestlasi ja leedulasi iseloomustavad individualistlikud ja maskuliinsed väärtused. Samas kasutavad leedulased ruuminormide rikkumise korral enam otsest verbaalset stiili (B), sarnanedes seega 1998. aastal vastanud eestlastega. 2006. aastal on eestlaste seas kasvanud C-variandi eelistajate hulk, millest võib järeldada, et eestlased on 8 aastaga muutunud ebakindlust paremini taluvaks. Leedulased taluvad võõrastega suheldes ebakindlust eestlastest halvemini.

\section{Järeldused ja diskussioon}

Majandusareng ja kiired muutused ühiskonnas võivad kultuuri muidu väga püsivaid väärtusi muuta (Inglehart, Baker 2000: 20). Eestlaste 1998. ja 2006. aasta küsitluse vahelisse aega jäi nii Eesti ühinemine NATO-ga kui ka liitumine Euroopa Liiduga. Kahe küsitluse tulemuste võrdlus näitab väärtuste erinevust: eesti kultuuris on toimunud mitmed väärtusnihked. Leedulaste väärtusmuutustest töökeskkonnas aastatel 1993-1997 on ülevaate andnud Virginius Lepeska (1999), praegustest väärtustest Audra I. Mockaitis (2005). Käesolev uurimus näitab, et väärtusmuutused Leedus jätkuvad. Leedu ruumikäitumine on eestlaste omast mitmekesisem, esile tulevad vastandlikud väärtused, muutuste suunda on keeruline määrata.

Uurimus näitab, et eelistused ja väärtused võivad erineda ka sõltuvalt keskkonnast: peresuhetes võivad esile tulla ühed kultuurinormid, töösuhetes ja vaba aega veetes teised.

\section{Kodune keskkond}

Kodust keskkonda puudutavate situatsiooniküsimuste puhul selgus, et 1998. aastal iseloomustasid eestlasi peresuhetes valdavalt kollektivistlikule ja feminiinsele kultuurile omased tunnused, kus eraldatusest olulisemaks peetakse suhteid teiste inimestega ning elukeskkonda eelistatakse privaatsusele (1. situatsiooni variandid $\mathrm{A} / \mathrm{C}$, 2. situatsiooni variant D). Ent esines ka vastaspoolus: ilusa keskkonna puudumist korvatakse ruumika majaga, kus igal pereliikmel oleks eraldumisvõimalus (1B), mis viitab individualistlike ja maskuliinsete väärtuste olemasolule kultuuris. 2006. aastal on väärtushinnangud veelgi enam jagunenud: suhteliselt palju vastanuid väärtustavad elukeskkonda ja tugevaid peresidemeid (1A/C, 2C/D), kuid suur on ka nende hulk, kelle jaoks on esmatähtis omaette olemise võimalus (1B, 2A). Seega, 1998. aasta ja 2006. aasta eestlaste küsitluste tulemusi võrreldes on koduses keskkonnas toimunud nihe kollektivistlikelt väärtustelt individualistlikele väärtustele. Kuna eestlaste materiaalne heaolu on tänaseks tunduvalt paranenud, võivad saadud tulemused kinnitada arvamust, et majanduslik areng suurendab kultuuris individualistlike väärtuste osakaalu: kui rahvuslik rikkus kasvab, on inimestel ressursse, mis võimaldavad neil lubada endale rohkem privaatsust ja individuaalseid otsuseid (vt Basabe jt 2002: 107, Schimmack jt 2005: 29). 
Leedulaste puhul on kodusuhetes näha, et nende jaoks on oluline elukeskkond, hoolitakse teistest inimestest ja tähtsustatakse sotsiaalset võrgustikku ning naabruskonda (1A/C, 2C/D). Seega kinnitavad saadud andmed A. Mockaitise (2005, vt ka tabel 1) uuringu tulemusi, mille kohaselt on leedulased eestlastest märgatavalt kollektivistlikumad. Näiteks, uude elukohta kolides jagavad eestlased kõigepealt toad pereliikmete vahel ära (2A), leedulased aga lähevad ja tutvuvad naabrite ja ümbruskonnaga (2C) ning lasevad osa vaheseinu maha lõhkuda, et tekiks avatud ruum (2D).

Vastuolu A. Mockaitise (2005) tulemustega tekkis aga maskuliinsuse-feminiinsuse dimensioonil. Nimelt on A. Mockaitise andmete põhjal leedu kultuur küllaltki maskuliinne, kuid käesoleva uurimuse põhjal võib oletada, et kodusuhetes iseloomustavad leedulasi pigem feminiinsed väärtused, nagu suhted kaasinimestega ja ilusa elukeskkonna eelistamine, mis korvab koduse ruumipuuduse.

Mõlema kultuuri kohta võib öelda, et oma pere keskel taluvad nii eestlased kui leedulased suhteliselt hästi ebakindlamaid olukordi. Pereliikmetele ei suruta peale fikseeritud distantse, vaid oluliseks peetakse suhtlemise mugavust - mööbli asukohta muudetakse vastavalt sellele, mida ruumis tehakse ja kellega seal suheldakse (3A).

\section{Töökeskkond}

Nii 1998. kui ka 2006. aasta eestlaste küsitlustest selgus, et töökeskkonnas suheldes on eestlastele omased individualistliku ja maskuliinse kultuuri tõekspidamised. Tööl keskendutakse eeskätt tööülesannetele ja -tulemustele, mistõttu soovitakse ka suuremat eraldatust. Samas ilmnes 2006. aasta küsitlusest, et privaatsust ei peeta enam nii oluliseks kui varem (5C). Privaatsust aitab hoida ka kaastöötajaga pilgukontakti vältimine ja hääle tasandamine või siis vaikimine (6A/C). Eestlane töötaks meeleldi nelja kolleegiga ühes ruumis. Kui 1998. aastal soovisid eestlased, et ruum oleks eraldatud vaheseintega (4B), siis 2006. aastal sooviti lisaks sellele samavõrra istuda nelja kolleegiga näod vastakuti (4C).

Võrreldes 1998. aasta tulemusi 2006. aasta vastustega, ilmnes erinevus ka töökaaslastega suhtlemisel. Kui esimesest küsitlusest saadi teada, et eestlased ei tähtsusta töökeskkonnas suhteid kaastöötajatega, siis 2006. aastal tulid esile feminiinse kultuuri väärtused - ka töökeskkonnas pööratakse inimsuhetele rohkem tähelepanu (7D) ning teist inimest ei jäeta suhtlusest kõrvale. Seega on toimunud kultuuris muutus: suhetes kaastöötajatega näeme liikumist maskuliinsetelt väärtustelt feminiinsetele.

Eestlaste otsus valida tööruumiks neljane kabinet ning nende valmisolek töökaaslastega suhelda võib olla tingitud vajadusest olla töös efektiivsem. Nimelt on kolleegidel, kel on sarnased tööülesanded ja ühine eesmärk, ühes ruumis tõhusam töötada. Väike distants kaastöötajate vahel muudab tööprotsessi efektiivsemaks, kuna kaastöötajad suhtlevad omavahel tihedamini (Kiesler, Cummings 2002, Nova 2005: 122 järgi). Mitteformaalne suhtlus on tööalase koostöö nurgakivi (Nova 2003: 10) ja arusaamine kolleegide tegevusest annab konteksti ka inimese enda tegevusele (Dourish, Bellotti 1992: 8).

Sarnaselt eestlaste tulemustele viitavad leedulaste andmed valdavalt individualistliku ja maskuliinse kultuuri väärtustele: tööl keskendutakse eeskätt töö- 
ülesannetele ega lasta end kõrvalistest asjaoludest häirida. Seega on eestlastel ja leedulastel ühine soov töötada privaatsuses. Tööruumi valikul soovivad leedulased, nagu eestlased, töötada nelja kolleegiga ühes ruumis, igal oma privaatne lahter (4B). Samas on leedulaste seas suhteliselt palju neid vastanuid, kes eelistavad töötada omaette kabinetis (4D). Kuna leedulased on eestlastest kollektivistlikumad (Mockaitis 2005), võib privaatne kabinet olla ka prestiiži tunnus.

Eestlaste ja leedulaste erinevus tuli esile töökaaslastega suhtlemisel. Leedulaste puhul on suhetes kolleegidega valdav, et neid ei jäeta suhtlusest kõrvale (7D) ning võimalusel sekkutakse ka ise vestlusesse (6D). Märgatavalt vähem on leedulaste hulgas vastanuid, kes inimsuhetest enam soovivad pühenduda tööle ja meelsamini hoiduks töökaaslastega suhtlemisest (6A/C).

Küsitlustest ilmnes, et nii leedulased kui ka eestlased taluvad suhteliselt hästi ebakindlamaid olukordi - mõlemad kultuurid peavad distantsihoidmist sotsiaalses suhtluses vajalikuks, kuid seda otseselt teisele inimesele peale ei suruta ja suhtluskonflikte püütakse vältida (8B, 9D). Samas on leedulaste seas suur hulk vastanuid, kes on valmis vastumeelse ruumikäitumise korral seda otsesõnu ka väljendama (8A, 9B), eestlased aga pigem väldivad otsest ütlemist.

Nii eestlaste mõlemast küsitlusest kui ka leedulaste omast selgus, et ühe kultuuri piires võib olla erinevate kultuuriväärtuste kandjaid. Kui kultuuris puudub domineeriv joon, on suhtluskonfliktid kerged tekkima. On küllaltki tõenäoline, et eesti kultuuris põrkuvad töökeskkonnas maskuliinsed ja feminiinsed väärtused (vt situatsioon 4, situatsioon 6), ning väärtused, mis on omased ebakindlust hästi taluvatele ja ebakindlust halvasti taluvatele kultuuridele (situatsioon 8). Leedulaste puhul on pilt veelgi kirjum: väärtuskonfliktid võivad esile tulla võimudistantsi erinevuste pinnal (situatsioon 9), ebakindlate olukordade talumise erinevuse pinnal (situatsioon 9, 10) ning maskuliinsete-feminiinsete väärtuseelistuste pinnal (situatsioon 6).

Domineerivate väärtuste puudumine ühiskonnas näitab, et väärtused on muutumas. V. Lepeska (1999) täheldas väärtuste teisenemist Leedus ka ajavahemikul 1993-1997. Ta tõi esile kollektivismi tugevnemise, võimudistantsi suurenemise, maskuliinsetelt feminiinsetele väärtustele ülemineku. Suhteliselt muutumatuna püsis aga ebakindluse talumine.

Käesolevas artiklis käsitletud töökeskkonda puudutavad tulemused ei toeta kõiki V. Lepeska (1999) seisukohti. Kuigi leedulaste kollektivistlikkus on eestlaste omast suurem (Mockaitis 2005, vt ka tabel 1), ilmnevad 2006. aastal leedulastel sarnaselt eestlastega töökeskkonnas pigem individualistlikule kultuurile omased jooned. Niisugune tulemus on kooskõlas ka N. Basabe jt (2002) ja U. Scimmacki jt (2005) andmetega, mis näitavad, et majanduslik areng suurendab ühiskonnas individualistlikke väärtusi. Ja kuigi leedulased on A. Mockaitise (2005) järgi eestlastest oluliselt maskuliinsemad (vt ka tabel 1), toetab käesolev uurimus V. Lepetska (1999) tulemusi leedulaste feminiinsete väärtuste esiletõusust: leedulased pööravad eestlastest enam tähelepanu töökaaslastele. Selline käitumine iseloomustab aga just pigem feminiinseid kultuure. Võimudistants on leedulastel eestlastest mõnevõrra suurem (Mockaitis 2005, vt tabel 1) ning seda kinnitas ka käesolev uurimus, samas aga ei ole leedulased võimuküsimustes täielikus üksmeeles - on neid, kelle vastused viitavad suurele võimudistantsile ja neid, kelle omad väiksemale võimudistantsile. 


\section{Suhted väljaspool kodu ja tööd}

1998. aasta ja 2006. aasta küsitlustest ilmnes, et väljaspool kodu- ja töökeskkonda suheldes on eestlaste ja leedulaste puhul olemas piir sotsiaalse ja isikliku ruumivööndi vahel, kus suhteid võõrastega ei peeta tähtsaks ning neid oma seltskonnaga liituma ei oodata (vt situatsioon 11). Ilmselt kannavad eestlased ja leedulased väljaspool kodu ja tööd individualistlikule maskuliinsele kultuurile omaseid jooni, kus suhtlusnormid ja distantsipiirid on selgelt määratletud. Leedulaste ja eestlaste erinevus tuli ilmsiks ebaselgetes suhtlusolukordades verbaalse stiili kasutamises. Nimelt reageerivad leedulased ebamugavates ruumilistes olukordades valdavalt resoluutselt ning oma privaatset ruumi otsesesõnu kaitstes (11A, 12B). Eestlastest annab suur osa mõista, et olukord on neile ebameeldiv, kuid oma viha ega ärritust keeleliselt ei väljenda $(11 \mathrm{D}, 12 \mathrm{C})$, kuigi oli ka neid vastanuid, kes sarnaselt leedulastega väljenduvad resoluutselt ja otsest verbaalset stiili kasutades $(11 \mathrm{~A}$, 12B). Saadud vastustest võib järeldada, et võrreldes leedulastega taluvad eestlased avalikus kohas ja võõrastega suheldes ebakindlaid olukordi paremini, mis kinnitab ka A. Mockaitise (2005, vt tabel 1) tulemusi leedulaste mõnevõrra halvemast ebakindluse talumisest. Vastuolu A. Mockaitise esitatud andmetega ilmnes aga individualismi-kollektivismi dimensioonil - erinevalt A. Mockaitise uurimusest ei ole käesoleva küsitluse tulemuste põhjal leedulastele avalikus suhtluses omased kollektivistliku kultuuri tunnused.

\section{Kokkuvõte}

Võrreldes 1998. ja 2006. aasta küsitluse tulemusi, iseloomustavad eestlasi koduses keskkonnas küll kollektivistlikud ja feminiinsed väärtused, ent ilmneb arengutendents individualistlike väärtuste suunas. Leedulaste 2006. aasta küsitlus näitas, et neile on koduses keskkonnas valdavalt omased kollektivistlikud ja feminiinsed väärtused. Eestlaste ja leedulaste ühisjooneks on suhteliselt hea ebakindluse taluvus.

Töösuhetes prevaleerivad eestlastel individualistlikud ja maskuliinsed tõekspidamised, kuid toimunud on nihe maskuliinsetelt väärtustelt feminiinsemate suunas. Leedulaste küsitlustulemused viitavad samuti valdavalt individualistliku ja maskuliinse kultuuri väärtustele, ent nende ruumikäitumine tööl on eestlaste omast märgatavalt mitmekesisem. Eestlastest suurem suhtlemine töökaaslastega näitab leedulaste feminiinseid väärtuseid. Võimudistants on leedulastel eestlaste omast suurem.

Suheldes väljaspool kodu- ja töökeskkonda, on eestlastele ja leedulastele iseloomulikud individualistlikule ja maskuliinsele kultuurile omased väärtused. Võrreldes leedulastega taluvad eestlased avalikus kohas ja võõrastega suheldes ebakindlaid olukordi paremini.

Olenemata suhtlussituatsioonist iseloomustab leedulasi enamasti resoluutsus ja otsene verbaalne stiil, eestlased seevastu keeleliselt end nii otseselt ei väljenda. 


\section{Kirjandus}

Adler, Ronald B.; Elmhorst, Jeanne Marquardt 1992. Communication at Work: Principles and Practices for Business and the Professions. New York: McGraw-Hill.

Altrov, Rene 1999. Eestlaste ruumikasutus suhtluses. Diplomitöö. Eesti Humanitaarinstituut. http://sinine.ehi.ee/ehi/oppetool/lopetajad/altrov/altrov.html (29.11.2006).

Basabe, Nekane; Paez, Dario; Gonzales, Jose Luis; Rimé, Bernard; Diener, Ed 2002. Cultural dimensions, socioeconomic development, climate, and emotional hedonic level. - Cognition and Emotion 16 (1), 103-125.

Dourish, Paul; Bellotti, Victoria 1992. Awareness and coordination in shared workspaces. J. Turner, R. Kraut (Eds.). Proceedings of CSCW'92: Conference on Computer Supported CooperativeWork. ACM Press, 107-114.

Hall, Edward T. [1966] 1990. The Hidden Dimension. Garden City, New York: Doubleday.

Hofstede, Geert H. 1980. Culture's Consequences: International Differences in Work-Related Values. Newbury Park, CA: Sage.

Hofstede, Geert H. 1993. Kulttuurit ja organisaatiot. Mielen ohjelmointi. Juva: WSOY.

Hofstede, Geert H. 2001. Culture's Consequences: Comparing Values, Behaviors, Institutions and Organizations Across Nations. Thousand Oaks, London, New Delhi: Sage Publications.

Hofstede, Geert H.; Bond, Michael H. 1984. Hofstede's culture dimensions. - Journal of Cross-Cultural Psychology 15, 417-433.

Gifford, Robert 1997. Enviromental Psychology: Principles and Practices. 2nd ed. Boston, London, Toronto, Sydney, Tokyo, Singapore: Allyn \& Bacon.

Gudykunst, William B.; Ting-Toomey, Stella 1988. Culture and Interpersonal Communication. SAGE Series in Interpersonal Communication. Newbury Park, CA: Sage Publications.

Gudykunst, William B.; Ting-Toomey, Stella; Sudweeks, Stawart; Steward, Lea P. 1995. Building Bridges: Interpersonal Skills for a Changing World. Boston: Houghton Mifflin.

Gudykunst, William B.; Ting-Toomey, Stella; Tsukasa, Nishida 1996. Communication in Personal Relationships Across Cultures. Thousand Oaks, London, New Delhi: Sage Publications.

Inglehart, Ronald; Baker Wayne E. 200o. Modernization, cultural change, and the persistence of traditional values. - American Sociological Review 65, February, 19-51.

Kiesler, Sara; Cummings, Jonathon N. 2002. What do we know about proximity and distance in work groups? A Legacy of research. - P. Hinds, S. Kiesler (Eds.). Distributed Work. Cambridge, MA: MIT Press, 57-80.

Lepeska, Virginijus 1999. Changes in psychological characteristics of working adults in different stages of economic transition in Lithuania. - Open Society Institute, Center for Publishing Development. Electronic Publishing Program, 1-9.

Mockaitis, Audra I. 2002. The national cultural dimensions of Lithuania. - Ekonomika 59, 67-77.

Mockaitis, Audra I. 2005. A cross-cultural study of leadership attitudes in three Baltic Sea region countries. - International Journal of Leadership Studies 1.1, 44-63.

Nova, Nicolas 2003. Socio-cognitive functions of space in collaborative settings: A literature review about space, cognition and collaboration. - CRAFT Research Report 1. École Polytechnique Féderale de Lausanne September 2003, 1-35. (Vt ka http://icwww.epfl. ch/publications/documents/IC_TECH_REPORT_200481.pdf (25.01.2007).)

Nova, Nicolas 2005. A review of how space affords socio-cognitive processes during collaboration. - PsychNology Journal 3 (2), 118-148. http://www.psychnology.org/ File/PNJ3(2)/PSYCHNOLOGY_JOURNAL_3_2_NOVA.pdf (25.01.2007).

Preston, Paul 2005. Proxemics in clinical and administrative settings. - Journal of Healthcare Management 50 (3), 151-154. 
Salo-Lee, Liisa; Malberg, Raija; Halinoja, Raimo 1996. Me ja muut. Kulttuurienvälinen viestintä. Helsinki: Yleisradio.

Schimmack, Ulrich; Oishi, Shigehiro; Diener, Ed 2005. Individualism: A valid and important dimension of cultural differences between nations. - Personality and Social Psychology Review 9 (1), 17-31.

Samovar, Larry A.; Porter, Richard 2004. Communication Between Cultures. Wadsworth Series in Speech Communication. Australia, Canada, Mexico, Singapore, Spain, United Kingdom, United States: Wadsworth/Thomson Learning.

Rene Altrov töötab Eesti Keele Instituudis, uurimisvaldkondadeks on kultuuridevaheline kommunikatsioon ja kõnekorpused.

rene.altrov@eki.ee 


\section{CULTURAL INFLUENCE ON PERSONAL SPACE USAGE AMONG ESTONIANS AND LITHUANIANS}

\section{Rene Altrov}

Institute of the Estonian Language

The article is based on a study that examined cultural influences on personal space usage in different communicative situations at home, at work, and spending one's leisure out of home and office. The aim of the study was to find out the rules governing the use of personal distance among Estonians and Lithuanians, wondering (1) if there could be some differences due to the communicative situation, (2) if there have been any changes in the Estonians' personal space behaviour, and (3) if any differences could be observed in the usage of personal space by Estonians and Lithuanians.

The questionnaire provided situations with four options of behaviour. The response was analysed relying on cultural studies by G. Hofstede and E. T. Hall. The informant groups consisted of ethnic Estonian and ethnic Lithuanian office workers. The Estonian data were gathered on two occasions - in 1998 and 2006, the Lithuanians were questioned in 2006.

The results demonstrated that values and preferences may differ depending on the communicative situation and environment: some cultural norms may work in family, some others at work or leisure. The comparison of the Estonian data of 1998 and 2006 reveals that in most cases the personal space behaviour of Estonians can be associated with certain individualistic and masculine values, but a transition from masculine values to feminine ones can be sensed. As for Lithuanians, their personal space behaviour is more variegated showing up several opposite values, depending on the situation.

Keywords: proxemics, proximity, spatial behaviour, interpersonal distance, personal space, Estonian, Lithuanian 